\title{
Nueva poesía de Argentina
}

Domingo Acosta

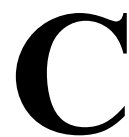

omo parte de un contexto con inquietudes latentes, pero a la vez fruto de una discontinuidad en lo social y político, lo que en verdad podríamos llamar Nueva Producción Poética de Argentina, lejos de resignar su actividad a un gesto de indulgencia -sin aceptar, tampoco, un cultivo del "testimonio por el testimonio"-, demuestra cómo dentro de una misma poética pueden darse marcadas diferencias. Si bien no estamos hablando de homogeneidades, uniformidades, no puede negarse que hay un camino en común en estas producciones poéticas.

Considerando la poesía como un trabajo de transformación del lenguaje, en ella veremos las controversias de su propio contexto, pero encontraremos la búsqueda hacia una consolidación de la forma como manifestación de lo social - unidad de expresión y contenido-, o al menos como inquietud que se afianza a partir de la producción de significaciones que se proyectan (en un giro constante) hacia el propio contexto desde el cual surgieran.

Dentro de esas inquietudes de transformación del lenguaje encontramos -en rasgos peculiares- tres actitudes. La revista de poesía XUL -signo viejo y nuevo de Buenos Aires, cuyo consejo editorial está compuesto por Roberto Ferro, Nahuel Santana y Jorge S. Perednik, presenta la característica de compartir una misma poética -en el plano ideológico-, pero con claras diferencias en el aspecto formal de sus textos; por ejemplo: Roberto Ferro trabaja sus poemas con la preeminencia del despliegue espacial de las palabras que así logran conseguir una correlativa sintaxis espacial (presentando, incluso, textos con distintos órdenes de lectura y preponderancia de la forma "plástica"). Nahuel Santana, pese a trabajar cierta espacialización en sus textos, recurriendo también a una sintaxis de características espaciales, no pasan de ser un recurso para facilitar la multiplicidad de sentidos que esos textos ofrecen al receptor; inquietud de la que tampoco escapa Ferro, sólo que en Santana esa búsqueda se centraliza en la elección formal de dos columnas, a través de las cuales se efectúa la variación sintáctica espacial, restringiendo, o "estandarizando", el desplazamiento de las palabras y/o versos.

En la producción de ambos autores se da una continuada reflexión sobre el proceso de la escritura (metapoesía, podría decirse) y de su recepción, aunque en el caso de Santana, éste no deje de dar cuenta -tambiénde la inmediatez social de su contexto. En Jorge S. Perednik se da cierta afinidad con ese rumbo "temático", aunque en sus textos 
prefiera volcar cierta conceptualidad, más bien lúdica, que "vela" poéticamente esa inmediatez, elaborando una desarticulación sintáctica y una rearticulación sintácticofónica, asociada al sarcasmo que desarrolla en un acercamiento a lo grotesco. Este gesto literario fue tipificado por Erich Auerbach como "dicción mezclada" (fusión de lo poéticamente "trascendente" y lo "vulgar" o coloquial), en su dicotomía "dicción pura"/ "dicción mezclada" (la "dicción pura" estaría determinada por el sentido tradicional de lo lírico del lenguaje poético y su tratamiento dado a un tema "serio").

Esta poética global, que unifica la producción de los tres autores mencionados, trata de concretar una nueva estructura (unidad de forma-expresión-ideología) -rechazando así hegemonías previas- y proponiendo al receptor de su producción poética un "trabajo de lectura" (o percepción estética) que posibilita develar significaciones existentes en el lenguaje.

Estas tres "actitudes" poéticas, como hemos visto, están abocadas al logro de significaciones más allá de lo que puede brindar la gastada programación previa del "mensaje", en tanto consideración simplificadora, o cristalizante, del texto poético.

Se intenta, a continuación, dar un acercamiento a lo enunciado, a través de un grupo de poemas de los autores citados en esta presentación. 


\section{ROBERTO FERRO}

\section{[Poema 1]}

El miedo

es

una suave provocación

un cuarto más allá de la mirada

una metáfora increíble

antes

el miedo

el miedo

cuando

empieza

a hurgar

las latitudes del silencio

se queda

un cuarto más acá de las palabras después

de las palabras

quedan

ecos

tartamudeos

apretados

a

la sombra

de algún fantasma

centinela del espanto. 


\title{
[Poema 2]
}

\author{
un \\ fragmento \\ el idilio entre \\ la mirada y la llanura
}
sombras que desnudan iluminaciones
repentinas apariciones simultáneas
bamboleantes enloquecidas volando
artesanos nuevos
distintos profundos
por el encuentro
repetido
cada
vez
en la piel del sentido
y el eco voluntario
de los ojos.




\section{NAHUEL SANTANA}

\section{[Poema 1]}

\section{EN LA/79, ASISTENTE SOCIAL DESOCUPADO DECLARA:}

No puede ser

esta ciudad

los cauces

donde muere

tanta gente

pasando

pasando

está la piel

este diario

centímetro

a la muerte

el cemento goteado contra el ojo.

Aquí no llama

no derrumba

$$
\text { el viento }
$$

la brisa

lo natural existe tan sólo en la memoria.

Ya ni la lluvia cae como entonces, sólo se acerca pasa y no regresa...

Ciudad debería ser

un campo claro

el día

de cuya noche

un hacedor levanta la mañana.

El verde río largo

la madera de fuego

$$
\text { del hombre }
$$

$$
\text { de su gesto }
$$

encendidio ardiendo consumido.

Pero algo de él

$$
\text { dentro }
$$

del tiempo-espacio

$$
\text { de la ciudad }
$$

-lo natural, el pie sobre la hierba

y el sol, 


$$
\begin{aligned}
& \text { un filo } \\
& \text { que resbala en la piel } \\
& \text { y no rasga la sombra. }
\end{aligned}
$$

\section{[Poema 2]}

Unidad mensurada.

Por la cesura

barrenado el centro,

moldeada como arcilla

en torno

de $(-)$ cadencias

cancerberas

rimas

concatenando

el madrigal del soneto en la epopeya

encabalgado

clímax

que (') de su nombre (?)

(Adonis,

del rococó pastoso de Marini)

(L'Allegria,

del hermetismo claro de Ungaretti)

tiene esta lenta historia, recortada,

fijada con la sal

ayer

y el sol, mañana. 


\section{JORGE SANTIAGO PEREDNIK}

\section{La exseñora de experiencia}

La vieja renga que llega siempre tarde me alcanzó la tarde en que la vieja obesa y ligera me alcanzó para decirme que sea otro distinto del otro que me digo y me dijo no te dejes/y fue como querer decir en una línea de... que la vieja renga que llega siempre tarde ábrete sésamo qué ojos grandes tienes abuelita es una anciana que aparece justo a tiempo rompiéndole el gesto a los muy duros es una anciana...jcómo duele! que está por nacer

\section{Doña Velázquez}

vasta o alargada hacia los tiempos

diminuta

su nombre es Velázquez le dicen aguijón pica

clava en la sangre una aguja minutera

empuja los tiempos con sus dos manos

hace trastabillar el tiempo con sus dos manos

tiene dos manos que luchan contra el tiempo

-tendencia al futuro-

Fuma como la ciudad (tenga a bien decir

no se olvide del) tesoro que guarda en sus pulmones

que ríe con un jajajá ijajajá?

que ríe con la risa de los dientes

y vela -bella- asquerosa-entera-sale-juega

redondear la estructura como un carpintero

¿Quién abre la puerta de vidrio? Nadie - decidirse-atravesar-

Toma una mano señala las líneas con su dedo

o hace pis o mientras hace pis

y dice el poema 


\section{El efecto "boomerang"}

hombre de dios el sabandija usa el dedo para acusar

la desnudez de la piel oscura como una astilla "y no habrá perdón"

en el afán de arrojar palabras puede ocurrir siendo palabra que un dedo de la piel oscura la tome y la devuelva

$\mathrm{y}$ haya que agachar

la desnudez de un rostro blanco "seguro pero es mi rostro"

cuando para otros hombres el rostro es el cuerpo entero

o quizás todos los cuerpos 